\title{
Molecular Detection of Group A Rotaviruses from the Bhandara and Chandrapur District of Maharashtra State, India
}

\author{
A. S. Kadam ${ }^{1}$, P. A. Tembhurne ${ }^{1 *}$ S. W. Bonde ${ }^{2}$, S. P. Chaudhary ${ }^{3}$, \\ N. V. Kurkure ${ }^{4}$ and V. C. Ingle ${ }^{1}$ \\ ${ }^{1}$ Department of Veterinary Microbiology and Animal Biotechnology, ${ }^{2}$ Veterinary \\ Biochemistry, ${ }^{3}$ Veterinary Public health, ${ }^{4}$ Veterinary Pathology; Nagpur Veterinary College, \\ Nagpur, MAFSU, Nagpur, Maharashtra-440006, India. \\ *Corresponding author
}

\section{A B S T R A C T}

\section{Keywords}

Rotaviruses, Latex agglutination test, RT-PCR, VP6, VP4 and VP7

\section{Article Info}

Accepted:

24 August 2019

Available Online:

10 September 2019
Animal Rotaviruses (RVs) are considered as major pathogen threats to humans and livestock due to neonatal mortality and possibility of interspecies transmission and exchange of genomic materials from human to animal species and vice versa. There are eight groups of rotaviruses (A to $\mathrm{H}$ ), among them mostly Group A mostly causes diarrhea in neonates and infants in humans and animals especially in cattle and buffalo worldwide. The present study was carried out to emphasize for molecular detection of circulating rotaviruses in Bhandara and Chandrapur districts of Maharashtra state in India. Ninety two (92) fecal samples collected from diarrheic and non diarrheic bovine calves (39 cow calves and 53 buffalo calves) were analyzed by conventional latex agglutination test (LAT) and amplification of VP6,VP7 and VP4 gene by RT-PCR and further analysis by G and P Typing PCR. From ninety two samples, ten samples were found positive by LAT, out of ten LAT positive samples, four samples showed expected $309 \mathrm{bp}$ amplicon for group specific VP6 gene. The VP4 and VP7 RT-PCR showed 864 bp and 1062 bp amplicons specific for VP4 and VP7 respectively in same two fecal out of ten positive samples. The G-typing PCR showed the G10 type strain is circulating whereas P type was untypable.Hence the present study concludes, the presence of group A Rotaviruses of G10 Type in Bhandara district and untypable rotaviruses in Chandrapur district of Vidharbha region of Maharashtra state in India.

\section{Introduction}

The Rotavirus is zoonotic important enteric viral pathogen suspected in wide host range in mammals and birds. It was reported to cross species transmission. The rotavirus led to diarrhea, emaciation and death in infants and calves. Rotavirus infects villous structure of small intestines where it lodges and multiplication occurred. The rotaviruses 
belongs to family Revoviridae, subfamily Sedoreovirinae of genus Rotavirus, which further composed of nine species namely Rotavirus A, Rotavirus B, Rotavirus C, Rotavirus D, Rotavirus E, Rotavirus F Rotavirus F, Rotavirus G, Rotavirus H, Rotavirus I (ICTV taxonomy (2018b). Rotaviruses are structurally icosahedral, triple layered and non-envelope viruses.

The genome is composed of 11 segments of double stranded RNA (ds RNA), which encode six structural (VP1, VP2, VP3, VP4, VP5, VP6 and VP7) and six non structural proteins (NSP1-NSP6). The VP6 protein is group specific inner capsid protein has high degree of nucleotide sequence conservation in different viral strains. The two outer layered proteins VP4 and VP7 are classified into P types and $G$ types respectively. These two proteins elicit neutralizing antibody response. Due to segmented nature of virus the two outer proteins VP4 and VP7 can segregate independently during reassortment, owing to which different $G$ types and $P$ types combinations could be found in co-circulating rotaviruses.

Rotavirus infection could be mild, moderate or severe. It varies from no symptoms to severe diarrhea, emaciation, body weight loss, no body weight gain in animals. It also causes economical burden to family due to treatment cost on the rotavirus disease, there is scanty data available in case of bovine rotavirus in Vidharbha region of Maharashtra. Farmers of Vidharbha region of Maharashtra are not much aware of the rotavirus infection in animals and human and cross transmission of viral infection. Hence, the study was planned to characterize and to study prevalence of bovine rotavirus circulating in Bhandara and Chandrapur district of Vidharbha region in Maharashtra where animal husbandry is well adopted and calf diarrhea and neonatal mortality is reported.

\section{Materials and Methods}

\section{Collection of samples}

Samples were collected from goshala, commercial dairy farms and unorganized farms in the months of August to September 2018. The total, ninety two (92) samples from both districts, forty four (44) from Bhandara (MS) and forty eight (48) from Chandrapur (MS) from the calf age 3 days to 90 days from diarrheic and non diarrheic bovine calves (39 cow calves and 53 buffalo calves). The fecal samples were collected from calves with diarrhea having consistency like semisolid, liquid, watery, and color greenish, yellowish, whitish, bloody diarrhea and non diarrheic at the time of samples collection but calves with history of frequently diarrhea before. Fecal samples were collected in sterile cotton swab from rectum of calves and kept on ice packs in cold chain transport box brought to Department of Veterinary Microbiology in Nagpur Veterinary College, Nagpur and kept in $-20^{\circ} \mathrm{C}$ for further investigation.

\section{Faecal suspension preparation}

A $10 \%$ fecal suspension was prepared in $2 \mathrm{ml}$ microcentrifuge tube in $1 \mathrm{X}$ phosphate buffered saline (PBS, pH 7.4) and clarified by centrifugation at $1000 \mathrm{~g}$ for 10 minutes in a refrigerated centrifuge (Biofuge primoR, Thermo Fischer Scientific, Germany) at $4^{\circ} \mathrm{C}$. The supernatant was transferred to fresh tube as clarified fecal/viral suspension and used as basic material for extraction of rotavirus RNA. The supernatant was stored at $-70^{\circ} \mathrm{C}$ till further use.

\section{Screening of samples by conventional method: Latex agglutination test}

Latex agglutination test was carried out using the commercially available HiRotavirus Latex Test Kit (Cat. No LK08-50NO Himedia,India) 
as per manufacturer's instructions. Ten percent fecal suspension was prepared into in 1.0 mililitre extraction buffer and allowed to settle down for larger particle and centrifuge for $1000 \mathrm{~g}$ for $10 \mathrm{mins}$. The $50 \mu \mathrm{l}$ inoculum was placed on LAT card wells and to this $20 \mu \mathrm{l}$ mixed rotavirus latex reagent (LK08a) to one well and $20 \mu \mathrm{l}$ of rotavirus control reagent (LK08b) to other well was added. The contents of each well were mixed by using a separate mixing stick for each well and spread thoroughly in well by gentle rocking the card and agglutination within two minutes was recorded.

\section{Molecular detection of rotaviruses}

\section{RNA-Extraction and cDNA Synthesis}

Total RNA was extracted from ten latex agglutination positive samples by Trizol Reagent LS (Cat.No.10296010, Invitrogen, USA) as per manufacturer's instructions with some modifications. All extracted RNA samples were quantified by Nanodrops machine (Thermo fisher Scientific, USA) and purity of RNA was checked by A260/280 and concentration checked in nanogram/microlitre(ng/ $\mu \mathrm{l})$. The cDNA Synthesis was performed using superscript III First-Strand synthesis system (18080-051) kit protocol with some modification. The reaction was performed in $0.2 \mathrm{ml}$ PCR tubes as followed $1 \mu \mathrm{l}$ of dNTPs $(10 \mathrm{Mm}), 2 \mu \mathrm{l}$ of DMSO, $2 \mu \mathrm{l}$ of Random hexamer $(50 \mathrm{ng} / \mu \mathrm{l})$ and $7 \mu \mathrm{l}$ RNA $(\sim 1-2 \mu \mathrm{g})$ was added and mixture was incubated at $95^{\circ} \mathrm{c}$ for $5 \mathrm{~min}$ and snap chilled in ice. To this mix, $2.5 \mu \mathrm{l}$ of $10 \mathrm{X}$ RT Buffer, $5 \mu \mathrm{L}$ of $\mathrm{MgCl}_{2}(25 \mathrm{mM}), 2.5 \mu \mathrm{l}$ of DTT $(0.1 \mathrm{M}), 1 \mu \mathrm{l}$ of DMSO and $1 \mu \mathrm{l}$ of Superscript enzyme $(200 U / \mu \mathrm{l})$ was added, mixed and briefly short spunned. The reaction was carried out as, $25^{\circ} \mathrm{C}$ for $10 \mathrm{~min}, 50^{\circ} \mathrm{C}$ for $50 \mathrm{~min}$ followed by $85^{\circ} \mathrm{C}$ for $5 \mathrm{~min}$. After completion of this reaction $1 \mu \mathrm{l}$ of RNAse $\mathrm{H}$ $(2 \mathrm{U} / \mu \mathrm{l})$ was added and further incubated at
$37^{0} \mathrm{C}$ for $20 \mathrm{~min}$. The cDNA was stored at -20 ${ }^{0} \mathrm{C}$ till further use.

Detection of Bovine Rotaviruses by Reverase Transcriptase- Polymerase Chain Reaction (RT-PCR)

\section{The amplification of VP6 for Rotaviruses}

The published Primer forward - Rot3 F5'AAA GAT GCT AGG GAC AAA ATT G3' and reverse- Rot5 R-5' TTC AGA TTG TGG AGC TAT TCC A3' was used in the study (Elschner et al., 2002). The PCR was carried out in $0.2 \mathrm{ml} \mathrm{PCR}$ tubes in $25 \mu \mathrm{l}$ total reactions volume containing $12.5 \mu \mathrm{l} 2 \mathrm{X}$ PCR Master Mix(Cat.No.PGK017-A,Puregene Genetix,India), $2 \mu 1$ of forward primer (10pmol/ $\mu \mathrm{l})$ and $2 \mu \mathrm{l}$ of reverse primer( $10 \mathrm{pmol} / \mu \mathrm{l}), 3 \mu \mathrm{l}$ of cDNA and $5.5 \mu \mathrm{l}$ of nuclease free water. The PCR was carried out in cyclic condition initial denaturation of $95^{\circ} \mathrm{C}$ for 5 minutes; followed by 40 cycles of denaturation at $95^{\circ} \mathrm{C}$ for $1 \mathrm{~min}$, annealing for $52^{0} \mathrm{C}$ for $1 \mathrm{~min}$, extension for $72^{0} \mathrm{C}$ for $1 \mathrm{~min}$ and final extension on $72^{\circ} \mathrm{C}$ for $10 \mathrm{~min}$. The PCR products were resolved in $1.5 \%$ agarose gel electrophoresis at $60 \mathrm{~V}$ for 1 hour in $0.5 \mathrm{X}$ TBE buffer in Electrophoresis unit (Banglore Genei,India)and documented using Geldoc system (Gel.ProCCD116, BioZen Laboratories, India).

The amplification of VP7 gene and VP4 gene for Rotaviruses

The amplification of VP7 gene was carried out using the published primer (Taniguchi et.al., 1992), targeting VP7 gene: forward -5'-GGC TTT AAA AGA GAG AAT TTC CGT CTG G-3' and reverse-5'-GGT CAC ATC ATA CAA TTC TAA TCT AAG-3'. The PCR was carried out in $0.2 \mathrm{ml}$ PCR tubes containing reaction mixture of $10 \mu \mathrm{l}$ PCR Master Mix $(2 \mathrm{X})$ (Puregene genetix Cat.No.PGK017A,India), $2 \mu \mathrm{l}$ of forward primer $(10 \mathrm{pmol} / \mu \mathrm{l})$ 
and $2 \mu \mathrm{l}$ of reverse primer $(10 \mathrm{pmol} / \mu \mathrm{l}), 1.5 \mu \mathrm{l}$ of cDNA, $1 \mu \mathrm{l}$ of DTT $(0.1 \mathrm{M})$ and $3.5 \mu \mathrm{l}$ of nuclease free water for the $20 \mu \mathrm{l}$ total reactions. The PCR was carried out with cycling conditions as initial denaturation of $95^{\circ} \mathrm{C}$ for 5 minutes, followed by 40 cycles of denaturation at $95^{\circ} \mathrm{C}$ for $30 \mathrm{sec}$; annealing at $55{ }^{0} \mathrm{C}$ for $1 \mathrm{~min}$ and extension at $72{ }^{\circ} \mathrm{C}$ for 2 min; and final extension at $72^{\circ} \mathrm{C}$ for 10 min. The PCR products were resolved in $1 \%$ agarose gel electrophoresis at $60 \mathrm{~V}$ for 1 hour in $0.5 \mathrm{X} \mathrm{TBE}$ buffer in Electrophoresis unit (Banglore Genei, India) viewed and documented using Geldoc system (ProCCD116 BioZen Laboratories, India.).

The amplification of VP4 gene was carried out using the published primer sequence Isegawa et. al.,(1993), forward 5'-TTC ATT ATT GGG ACG ATT CAC A-3' and reverse primer 5'-CAA CCG CAG CTG ATA TAT CAT C-3'. The PCR was carried out in $0.2 \mathrm{ml}$ PCR tubes containing reaction mixture as above mentioned reaction.The PCR was carried out with cyclic condition as initial denaturation of $95^{\circ} \mathrm{C}$ for $5 \mathrm{~min}$, followed by 40 cycles of denaturation at $95{ }^{\circ} \mathrm{C}$ for $30 \mathrm{sec}$; annealing at $52{ }^{\circ} \mathrm{C}$ for $1 \mathrm{~min}$, extension at $72^{\circ} \mathrm{C}$ for 1 minute and the final extension was carried out at $72^{\circ} \mathrm{C}$ for $10 \mathrm{~min}$. The PCR products were resolved in $1 \%$ agarose gel in $0.5 \mathrm{X}$ TBE buffer in Gelectrophoresis unit (Banglore Genei,India) viewed and documented using Geldoc system (ProCCD116 BioZen Laboratories, India).

\section{$G$ and $P$ genotyping}

The amplified positive PCR products for VP7 gene were further processed for G-typing. The amplified products were diluted 1:50 in nuclease free water (NFW) and from diluted product $3 \mu \mathrm{l}$ was used for typing reaction. The reaction was prepared in $0.2 \mathrm{ml}$ PCR tube with $5 \mu l$ of reverse primer $(10 \mathrm{pmol} / \mu \mathrm{l})$ reverse-5'GGT CAC ATC ATA CAA TTC TAA TCT
AAG-3' and G-typing cocktail each published primer $1 \mu 1$ (G3,G5,G6,G8 and G10), the mixture of $25.0 \mu \mathrm{l}$ PCR Master $\operatorname{Mix}(2 X)($ Puregene genetixCat.No.PGK017A,India), $2 \mu \mathrm{l}$ of $\mathrm{DTT}(0.1 \mathrm{M}) ; 10.0 \mu \mathrm{l}$ of nuclease free water adjust the $50 \mu$ l total reactions. All components were mixed properly by tapping and briefly spunned. The PCR tube kept in thermocyler and cycling condition was set same for VP7 amplification.

The amplified positive PCR products for VP4 gene were processed for P-typing. The positive amplified PCR products were diluted 1:50 and from diluted product $3 \mu 1$ was used for typing. The reaction was prepared in 0.2 $\mathrm{ml}$ PCR tube with $2 \mu \mathrm{l}$ of forward primer(10pmol/ $\mu$ l Forward -5'-TTC ATT ATT GGG ACG ATT CAC A-3 and P-typing cocktail each published primer $1 \mu$ of $\mathrm{P}[1]$, $\mathrm{P}[5]$ and $\mathrm{P}[11]$ the mixture of $10.0 \mu \mathrm{l}$ PCR Master Mix $(2 \mathrm{X})$ (Puregene genetix Cat.No.PGK017-A,India), $1 \quad \mu l \quad \mathrm{MgCl}_{2}$ $(50 \mathrm{mM}), 1 \mu \mathrm{l}$ of DTT $(0.1 \mathrm{M})$ and $1.0 \mu \mathrm{l}$ of nuclease free water in the $20 \mu \mathrm{l}$ total reactions. All components were mixed properly by tapping with briefly spunned. The PCR tubes were kept in thermocyler and cycling condition was set same VP4 amplificationtyping and P-typing amplified PCR products were resolved in a $1 \%$ agarose gel in $0.5 \mathrm{X}$ TBE buffer in Gelectrophoresis unit (Banglore Genei,India) viewed and documented using Geldoc system (ProCCD116 BioZen Laboratories, India).

\section{Results and Discussion}

Bovine Rotavirus infection leads to morbidity and mortality in calves of age between first week to 24 weeks that result into substantial economic losses to dairy industry throughout the world and immensely in developing and undeveloped countries. In Maharashtra State, in Vidharbha region, dairy industry is well developed in Bhandara and Chandrapur 
district. In these districts, calves diarrhea and neonatal mortality was reported, hence the present study was planned to analyze the circulating rotavirus infection by characterizing them by conventional and molecular approaches.

\section{Detection of Rotaviruses by Latex agglutination test}

In the present study, the ninety two (92) fecal samples from diarrheic and nondiarheic calves were tested by Latex agglutination test showed that $10(10.86 \%)$ samples were positive for Rotaviruses. In Bhandara district total six (13.63\%) fecal samples were positive for rotavirus infection, out of forty four(44) fecal samples from buffalo calves, 04 (18.18\%) fecal samples and $02(9.09 \%)$ from cow calves were positive. In Chandrapur district samples, out of 48 samples, 04 (8.33\%) samples were positive for rotavirus infection by LAT from buffalo calves only. The present study indicated the buffalo calves were more affected in both the districts. The representative positive samples and negative for LAT is depicted in figure 1. Other researchers also reported that out of 53 diarrheic fecal samples screened for rotavirus infection in buffalo calves and cow calves, the LAT showed 17(32.08\%) samples were positive (Singh and Jhala 2011). The current findings resemble with another study conducted in Maharashtra reported that out of 58 bovine calf fecal samples screened for rotavirus infections only 4 samples $(6.89 \%)$ were positive by rapid rotavirus antigen detection kits (Tumlam et al., 2018), and also in another study conducted in Amravati region of Maharashtra reported that out of 288 samples 35 samples were positive for rotavirus infection by LAT (Ade et al., 2019). The bovine rotaviruses infection was variable in degree of incidence reported with various study by researchers with factor like geographilic area, climatic conditions, species of animals, sex of animal, season of calving, managmental practices. The LAT is feasible for primarily screening, cost of kit is less and easy to perform.

\section{Detection of Rotaviruses by Reverase Transcriptase- Polymerase Chain Reaction (RT-PCR)}

\section{Detection of bovine Rotaviruses by RT-PCR with group specific VP6 gene}

The ten (10) LAT positive samples were analyzed by molecular approach using group specific VP6 reverse transcriptase polymerase chain reaction (RT-PCR). The VP6 gene based RT-PCR yielded a specific product 309 bp in 03 samples from Bhandara districts and one samples from Chandrapur district figures 2. In another study Suresh et al., (2011) reported that 27 samples were positive out of 112 by VP6 gene based RT-PCR, similarly another study Tumlam et al., (2018) showed that four samples were positive for VP6 gene by RT-PCR out of fifty eight fecal samples while Basera et al., (2010) studied that 10 samples were positive by group specific VP6 gene out of thirteen positive RNA-PAGE sample out of screened 128 diarrheic fecal samples from bovine calves. In another similar studies Ved et al., (2016) reported that amplification of group specific VP6 gene based RT-PCR showed 50/157 cattle samples and 29/61 buffalo samples were positive.

From these studies it was observed that RNA PAGE, LAT, do not corroborate with RT-PCR detection owing to inhibitors in fecal sample for RT-PCR, or due to stages of disease and duration of sample collection for testing. In the present study LAT positive samples were analyzed however it was interesting to note that only buffalo calves samples were found positives, due to smaller sample size we can conclude that as buffaloes calf might be more severely affected or susceptible over cow calf. 
Table.1 Primers used for G and P typing of Bovine Rotaviruses.

\begin{tabular}{|c|c|c|c|c|}
\hline Primer & Sequence 5'-3' & Position & $\begin{array}{l}\text { Amplicon } \\
\text { size(bp) }\end{array}$ & Reference \\
\hline G3 & CGT TTG AAG AAG TTG CAA CAG & $689 \sim 709$ & 373 & $\begin{array}{l}\text { Gouvea } \\
\text { al.,(1990) }\end{array}$ \\
\hline G5 & GAC GTA ACA ACG AGT ACA TG & $760 \sim 779$ & 302 & \multirow{2}{*}{$\begin{array}{l}\text { Gouvea } \\
\text { al.,(1994) }\end{array}$} \\
\hline G6 & GAT TCT ACA CAG GAA CTA G & $481 \sim 499$ & 581 & \\
\hline G8 & GTC ACA CCA TTT GTA AAT TC & $178 \sim 197$ & 884 & $\begin{array}{l}\text { Gouvea } \\
\text { al.,(1990) }\end{array}$ \\
\hline G10 & ATG TCA GAC TAC ARA TAC TGG & $666 \sim 686$ & 396 & $\begin{array}{l}\text { Iturriza-Gomara } \\
\text { et al., (2004). }\end{array}$ \\
\hline $\mathbf{P}[1]$ & TTA AAT TCA TCT CTT AGT TCT C & $1526 \sim 1505$ & 460 & \multirow{3}{*}{$\begin{array}{l}\text { Isegawa et al., } \\
(1993)\end{array}$} \\
\hline $\mathbf{P}[5]$ & GGC CGC ATC GGA TAA AGA GTC C & $1725 \sim 1704$ & 659 & \\
\hline $\mathbf{P}[11]$ & TGC CTC ATA ATA TTG TTG GTC T & $1398 \sim 1377$ & 332 & \\
\hline
\end{tabular}
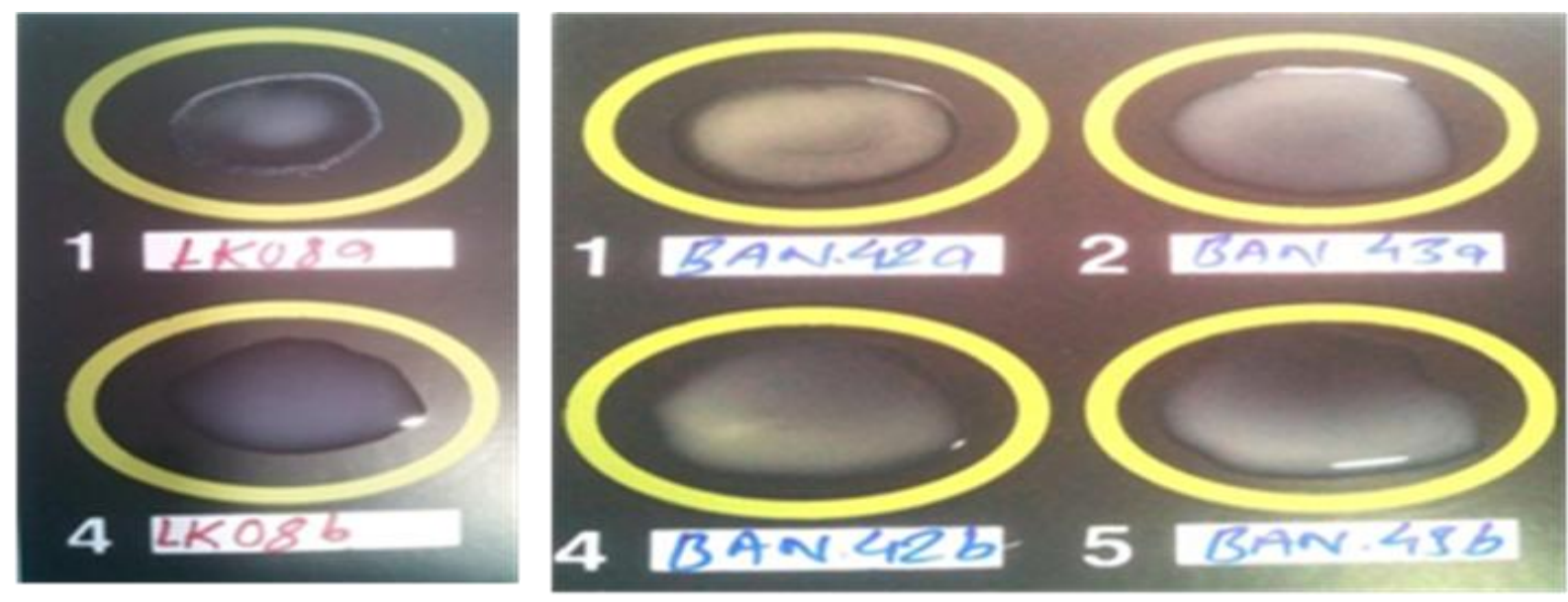

Figure 1. L atex Agglutination test for group A rotavirus.

LKoSa-Positive Control, LKaSb-Negative control.

BAN42 a-Positive Sample, BAN42b-Negative control. BAN43a-Negative sample, BAN-43b-Negative control. 


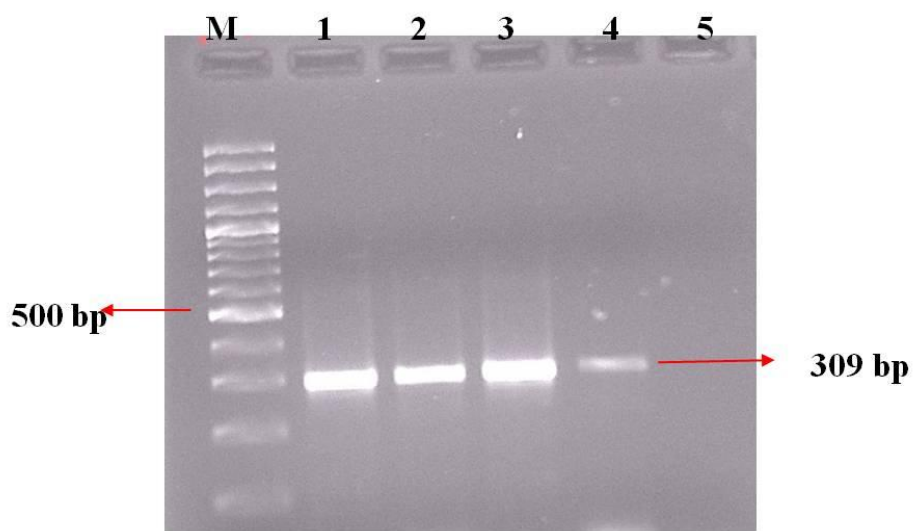

Figure 2: Agarose gel electrophoresis confirming amplicons of rotavirus by VP6 gene RT-PCR.

Lane M: 100bp Marker (Cat No.SM0321, Thermo Scientific, India)

Lane 1: BAN-42 Positive sample Lane2: BAN-33 Positive sample Lane3: BAN-31 Positive sample Lane4: CAN-19 Positive sample Lane5: Negative control

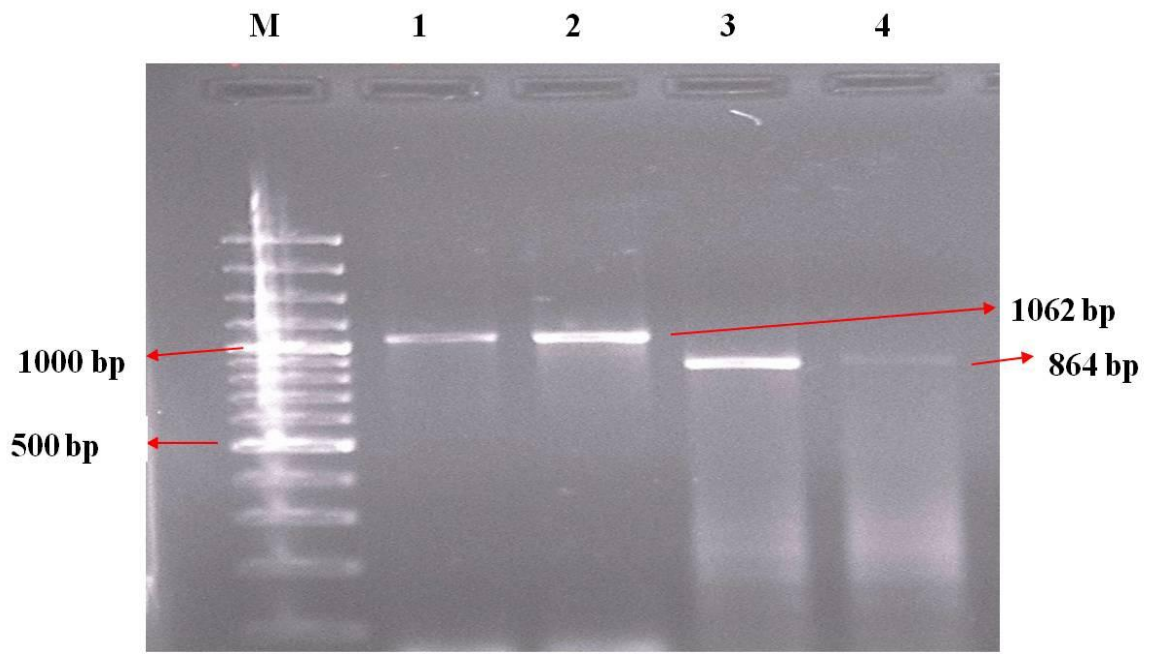

Figure 3 . Agarose gel electrophoresis confirming the amplicons of Rotavirus by VP7 and VP4 gene RT-PCR M-Marker 100 bp (Cat No.SM0321, Thermo Scientific, India) Lane-1: B 42 sample Bhandara positive for VP7 Lane-12-B31 sample Bhandara positive for VP7 Lane-13-B42 sample Bhandara positive for VP4 Lane-14-B31 sample Bhandara positive for VP4 


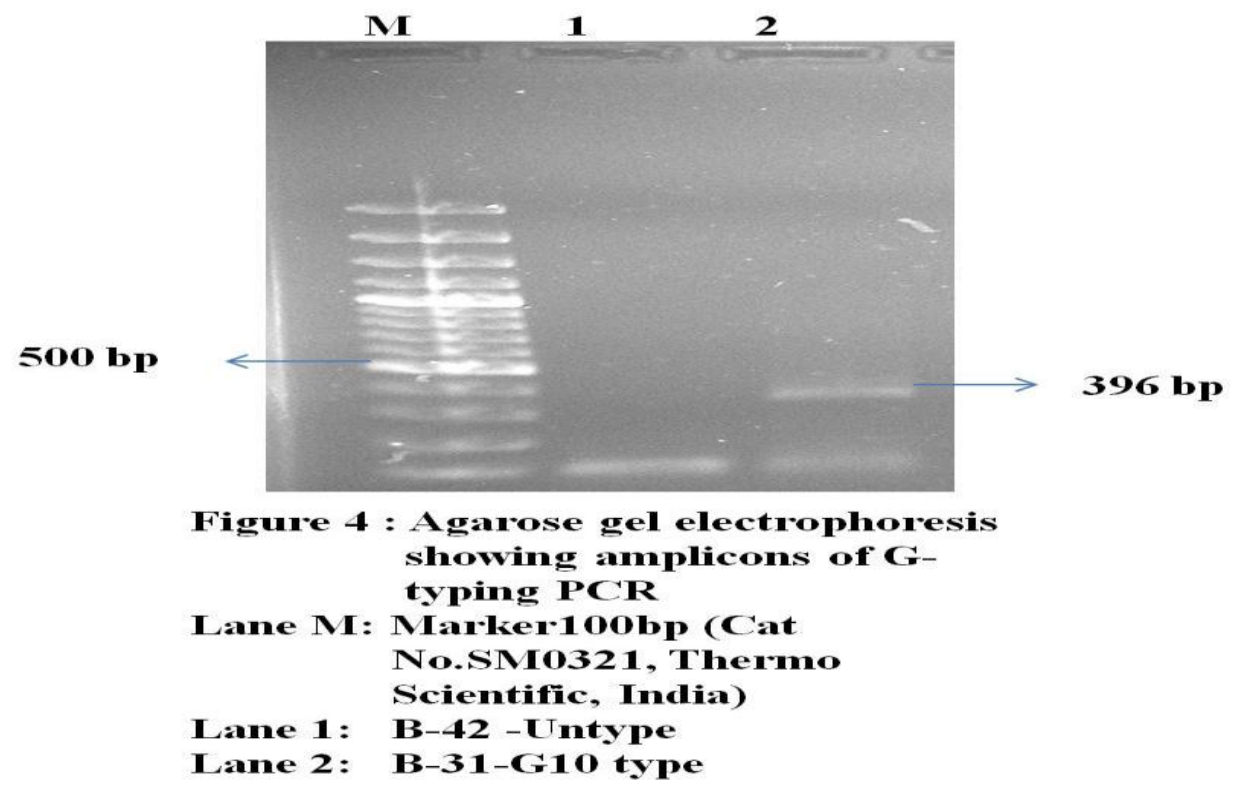

Detection of bovine Rotaviruses by RT-PCR with VP7 and VP4 gene

The LAT positive ten samples were further processed for VP7 gene and VP4 RT-PCR, it was observed that out of ten samples only two same B31 and B42 samples were positive for specific amplification $1062 \mathrm{bp}$ for VP7 gene and 864 for VP4 gene. Both these fecal samples were from Bhandara districts as shown in figure 3 . None of the samples from the Chandrapur districts were amplified by both (VP7 and VP4) gene specific RTPCR.The researcher Chandrasekhar et al., (2013) also reported that 25 positive samples from out of 184 fecal samples by full length VP7 gene. The Kashikar et al.,(2018) reported that three (3) samples, out of six positive samples were positive by RNA-PAGE in buffalo calves diarrhea were successful amplified with specific amplicon size. Current results were also agreement with the Sravani et al., (2014) who reported that 17 samples were amplified for VP7 gene and four samples were amplified for VP4 gene out of 120 fecal samples were screened for RT-PCR. The researcher Ade et al., (2019) reported that only one fecal sample was positive for amplification of VP4 gene out of 35 LAT positive samples might be due to the presence of inhibitory substances in the fecal samples. The researcher Mukhtar et al., (2016) reported that five fecal samples showed the specific amplification for VP4 gene by RT-PCR out of 12 ELISA positive samples obtained from screening of 200 fecal samples. The present study delineated that the PCR positivity is varied might be due to inhibitory factors or mismatched with 3' end of primer binding sites in Indian rotaviral strains.

\section{$G$ and $P$ genotyping}

Two samples were analyzed for $\mathrm{G}$ and $\mathrm{P}$ types in this study, one samples revealed specific amplified product for $396 \mathrm{bp}$ as shown in figure 4, indicating G10 strain and one samples was untypeble, while none of the samples were shown specified amplification for P type namely $\mathrm{P}[1], \mathrm{P}[5]$ and $\mathrm{P}[11]$. It was observed that G10 genotype was predominant in past several studies, Gulati et al.,(1999) reported a frequency of G10 genotypes 83\% isolated in Haryana and U.P, similarly, Wani et al., (2004) reported that six out of ten sample were G10 type. In Madhya Pradesh (M.P.), central province of India Chandrasekhar et al., (2013) studied that 
circulation of divergent strains of G10 genotypes. The present study findings is contraindicated to the another study carried out by Niture et al.,(2011) where he reported that six samples shown positive amplification for VP7 gene specific amplification but none of the samples revealed to G6,G8 and G10 type specific products but two samples amplified for $\mathrm{P}[11]$ from six positive amplification VP4 gene. The researcher Beg et al., (2010) reported that 25 samples (80.64\%) revealed amplified products to G10 while three samples possessed G8 genotype, two sample were not amplified for by any $\mathrm{G}$ typing specific primer and none of the samples was amplified for G5 strain and while 31samples revealed for $\mathrm{P}$ [11] amplification and none of the samples amplify for P [1] and [P5].

In conclusion the overall studies revealed that rotavirus infection can be detected by LAT in bovine fecal sample in a short time. It can be used on field test performance on farmer's doorstep, useful for early diagnosis of rotaviral diarrhea in calves and to avoid further economical losses in livestock by giving supportive therapy. The buffalo calves showed more positivity to rotaviruses infection than cow calves, however it required large data to conclude the susceptibility and severity of disease in these calves. However for rotavirus confirmation more than one test should be performed to avoid the false positivity/ negativity due to variation of amplification observed and LAT result correlation, it required further more data to conclusive remarks. The $\mathrm{G}$ typing indicated the G10 type in Bhandara districts however further typing by sequencing to further validates these isolate. Therefore molecular epidemiology needs to be carried out.

\section{Acknowledgement}

The authors are thankful to the Dean, Nagpur Veterinary College, Nagpur for providing facilities and also to Indian council of Medical Research (ICMR),New Delhi (Sanction letter No.ZON/23/1/2017-ECD-II)) for projects funds to the institute.

\section{References}

Ade M.J., Ingle V.C., Tembhurne P.A., Kadam A.S.,Bhojne G.R., and Sonkusale P.M., 2019. Incidence and prevalence of rotaviruses of cattle and buffallo calves in Amravati Region, Maharashtra. Indian J.Vet Sci.Biotech 14(3):20-23.

Basera S.S., Singh R.,Vaid N.,Sharma K.,Chakravarti S.,Malik Y.P.S.,2010.Detection of rotavirus infection in bovine calves by RNA-PAGE and RT-PCR.Indian J. Virol. 21(2):144147.

Beg S.A., Wani S.A., Hussain I.and Bhat M.A., 2010. Determination of $G$ and $P$ types diversity group A rotaviruses in fecal samples of diarrheic calves in Kashmir, India.Letters in Applied Microbiology 51,595-599.

Chandrashekar K.M.SharmaK.,Prasad M.,KumarN.,MalikY.P.S.,2013.Genetic Characterisation of Group -A rotavirus detected in diarrhoeic bovine calves in Madhya Pardesh. Journal of immunology and immunopathology 15(2):163-16

Elschner M., Prudlo J., Hotzel H., Otto P. and Sachse K.,2002.Nested Reverse Transcriptase-Polymerase Chain Reaction for the Detection of Group A Rotaviruses.J. Vet. Med. B 49:77-81.

GouveaV., GlassR.I.,Woods P.,Taniguchi K.,Clark H.F.,Forrester B.,Fang Z.Y.,1990.Polymerase chain reaction amplification and typing of rotavirus nucleic acid from stool speciemens.J Clin Microbiol.28:276-

Gouvea V., Santos N., Timenetsky Mdo C., 1994. Identification of bovine and porcine rotavirus $G$ types by PCR.J Clin Microbiol.32:1338-1340.

Gulati B.R.,Nakagomi O., Koshimura Y., Nakagomi K., and Pandey R.,1999.Relative frequencies of $\mathrm{G}$ and $\mathrm{P}$ types among rotaviruses from Indian 
diarheic cow and buffalo calves. J Clin Microbiol 36, 2074-2076.

ICTV taxonomy, 2018b http://ictvonline.org/ virusTaxonomy.asp

Isegawa, Y., Nakagomi O., Nakagomi T., Ishida S., Uesugi S. and Ueda S., 1993.Determination of bovine Rotavirus $G$ and $\mathrm{P}$ serotypes by polymerase chain reaction. Molecular and Cellular Probes, 7: 277- 284.

Iturriza Go'mara M., Kang G.,and Gray J.,2004.Rotavirus genotyping: keeping up with an evolving population of human rotaviruses.J Clin Virol.31:259-265

Kashikar O.S., Deshpande A.R., Suryawanshi P.R., Gaikwad S.S., Kashikar S.S.,2018.Molecular characterization and phylogenetic analysis of bovine and human rotavirus. Journal of Entomology and Zoology Studies 6(5)706-709.

Mukhtar N.,Yaqub T.Masood A.Javed H.,Nazir A.,Aslam A.,Ali Akhtar,Javed M.,Nadeem A.,Hussain T.,Tahir Zarfashan and Aslam H.B.2016.Molecular characterization of bovine rotaviruses in Pakistan.Junidshapur J Microbiol.9(12)e41001:1-5

Niture G.S., Karpe A.G., and Prasad M., 2011. Characterization of buffallo, poultry and human rotaviruses in western India.Vet.archiv 81(3), 307-319.

Singh T.C. and Jhala M.K., 2011.Comparing relative sensitivity and specificity of LA and RNA-PAGE in detecting bovine rotaviruses. Buffalo Bulletin 30(1):36-40.
Sravani G.V.D.,Kaur G.,Chandra M. and Dwiedi P.N., 2014. P and G genotyping of bovine rotavirus and its prevalence in neonatal calves. Vet Archiv 84(5):475-484

Suresh T.Rai R.B., Dhama K.,Bhatt P.,Sawant P.M.,and Sharma A.K.,2011.Detection of group A bovine rotavirus in diarrheic calves by reverse transcriptase chain reaction(RT-PCR) and electropherotyping. Veterinary practioner 12(2):133-137.

Taniguchi K., Wakasugi F., Pongsuwanna Y.,Urasawa T.,Ukae S.,Chiba S.,Urasawa S.,1992.Identification of human and bovine rotaviruses serotypes by polymerase chain reaction Epidemol Infect, 109:303-312.

Tumlam U.M.,Ingle V.C., Tembhurne P.A., Kurkure N.V., Chaudhari,Chitamber S.D. and Bhoyar S.,2018.Detection of VP6 gene of rotavirus in feces of diarrheic calves,kids,lambs,piglets,pups and human infants by reverse transcriptasepolymerase chain reaction. Indian J.Vet Sci.Biotech 13(4):12-16

Ved N., Srivastav B.R., Sharma K., Yadhav N., and Malik Y.S. 2016.G and P typing of bovine group A rotaviruses isolated from northern and central India.J.Vet.Pub.Hlth.14((1):1-7.

Wani S.A., Bhat M.A., Ishaq S.M.,Ashrafi M.A.,2004.Determination of bovine rotavirus $\mathrm{G}$ genotypes in Kashmir, India. Revue Sci. Tech OIE 23:931-936.

\section{How to cite this article:}

Kadam, A. S., P. A. Tembhurne, S. W. Bonde, S. P. Chaudhary, N. V. Kurkure and Ingle, V. C. 2019. Molecular Detection of Group A Rotaviruses from the Bhandara and Chandrapur District of Maharashtra State, India. Int.J.Curr.Microbiol.App.Sci. 8(09): 2555- 2564. doi: https://doi.org/10.20546/ijcmas.2019.809.296 